\title{
Moringa oleifera fruit induce apoptosis via reactive oxygen species-dependent activation of mitogen-activated protein kinases in human melanoma A2058 cells
}

\author{
TAE EUN GUON and HA SOOK CHUNG
}

Department of Food and Nutrition, College of Natural Sciences, Duksung Women's University, Seoul 01369, Republic of Korea

Received September 24, 2016; Accepted March 9, 2017

DOI: $10.3892 / \mathrm{ol} .2017 .6288$

\begin{abstract}
The present study was performed to determine the effect of Moringa oleifera fruit extract on the apoptosis of human melanoma A2058 cells. A2058 cells were treated for $72 \mathrm{~h}$ with Moringa oleifera fruit extract at 50-100 $\mu \mathrm{g} / \mathrm{ml}$, and cell viability with apoptotic changes was examined. The involvement of reactive oxygen species (ROS) and mitogen-activated protein kinases (MAPKs) was examined. It was revealed that Moringa oleifera fruit extract significantly inhibited the cell viability and promoted apoptosis of A2058 cells in a concentration-dependent manner. Moringa oleifera fruit extract-treated A2058 cells exhibited increased activities of cleaved caspase-9 and caspase-3. It also caused an enhancement of MAPK phosphorylation and ROS production. The pro-apoptotic activity of Moringa oleifera fruit extract was significantly reversed by pretreatment with the c-Jun N-terminal kinase (JNK) inhibitor SP600125, extracellular-signal-regulated kinase (ERK) inhibitor PD98058 or ROS inhibitor N-acetyl-L-cysteine. Taken together, Moringa oleifera fruit extract is effective in inducing mitochondrial apoptosis of A2058 cells, which is mediated through induction of ROS formation, and JNK and ERK activation. Moringa oleifera fruit extract may thus have therapeutic benefits for human melanoma A2058 cells.
\end{abstract}

\section{Introduction}

Malignant melanoma is the most serious type of skin cancer and develops in melanocytes that produce melanin pigment (1). The most common site of malignant melanoma is the upper back, although it also occurs in the arms and legs (2). Previous studies have demonstrated that age, skin type and a family history of melanoma significantly affect the development

Correspondence to: Professor Ha Sook Chung, Department of Food and Nutrition, College of Natural Sciences, Duksung Women's University, 33 Samyang-Ro, Dobong-Gu, Seoul 01369, Republic of Korea

E-mail: hasook@duksung.ac.kr

Key words: Moringa oleifera fruit, A2058 cells, human melanoma cells, oxidative stress, mitogen-activated protein kinases, apoptosis of malignant melanoma. Surgery is the main treatment for early-stage malignant melanoma (3). However, there is no available treatment when melanoma passes early stage, or upon recurrence, making it an incurable disease with a high rate of metastasis $(4,5)$. Moringa oleifera Lam is a tree of the Moringaceae family that can reach a height of between 5 and $10 \mathrm{~m}$ (6). Moringa is cultivated in Asia, Africa and Arabia, and is a good source of nutrition, since the plant is rich in proteins and vitamins (7). It has various pharmacological effects, including anti-hyperglycemic, anti-inflammatory and anticancer functions (8). Moringa leaves are the most nutritious part, as they are rich in $\beta$-carotene, proteins, vitamin C, calcium and antioxidants (9). There are two types of cell death process: Apoptosis and necrosis. Apoptosis is an important physiological mechanism in which apoptotic cells cause immune responses for removal of dead cells without destruction of surrounding cells, leading to characteristic cell changes, including cell shrinkage and membrane blebbing (10). This active process is mediated under the control of gene regulation (11). Reactive oxygen species (ROS) induce cancer and aging, formation of lipid peroxides, destruction of proteins and nucleic acids, and inhibition of various enzyme functions by attacking living cells. ROS are also mediators of intracellular signaling (12). However, excessive ROS production increases oxidative stress, resulting in cellular damage and inhibition of cellular functions and the cell cycle to cause apoptosis $(13,14)$. Chemotherapeutic agents, including anticancer agents, exert relatively marked toxic effects, although certain cancer cells exhibit resistance. Once cancer cells acquire resistance to a particular anticancer agent, they have resistance to all anticancer agents operating via the same mechanism (15). Therefore, anticancer agents derived from natural compounds have been developed with decreased side effects and increased anticancer activity $(16,17)$. It is important for patients to strengthen their immune systems upon occurrence of malignant melanoma. As synthetic anticancer agents may weaken the immune system, more studies on natural products for treatment of malignant melanoma are required. For the identification of cytoprotective agents from natural resources, the present study investigated the cytoprotective mechanisms underlying Moringa oleifera fruit, against mitochondrial apoptosis with respect to the induction of ROS formation, and c-Jun $\mathrm{N}$-terminal kinase (JNK) and extracellular-signal-regulated kinase (ERK) activation in human melanoma A2058 cells. 


\section{Materials and methods}

Plants and sample extraction. Moringa oleifera fruit (MOF) were collected at Dar es Saalam, Tanzania, in September 2013. Botanical identification was made by Professor Henry Joseph Hjndangalasi, Department of Botany, Dar es Salaam University, Dar es Salaam, Tanzania. Dried MOF (13.0 g) were soaked in $70 \%$ ethanol and sonicated $(40 \mathrm{kHz})$ for $3 \mathrm{~h}$ at room temperature. Extracts were evaporated in a dry oven at $60^{\circ} \mathrm{C}$ and stored at $-20^{\circ} \mathrm{C}$ until used for the in vitro assay (yield, $0.2794 \mathrm{~g})$.

Chemicals and reagents. MTT and propidium iodide were purchased from Sigma-Aldrich (Merck KGaA, Darmstadt, Germany). Primary mouse monoclonal antibodies against $\beta$-actin (catalog no. sc-47778; dilution, 1:1,000) and rabbit monoclonal antibodies against B-cell lymphoma-2 (Bcl-2; catalog no. sc-492; dilution, 1:1,000) and Bcl-2-associated $\mathrm{X}$ protein (Bax; catalog no. sc-493; dilution, 1:1,000) were purchased from Santa Cruz Biotechnology, Inc. (Dallas, TX, USA). Rabbit monoclonal antibodies against cleaved caspases-3 (dilution, 1:1,000; catalog no.9661),-8 (dilution, 1:1,000; catalog no. 8592) and -9 (dilution, 1:1,000; catalog no. 7237) and poly (ADP-ribose) polymerase (PARP; dilution, 1:1,000; catalog no. 5625) were purchased from Cell Signaling Technology, Inc. (Danvers, MA, USA). Horseradish peroxidase (HRP) -conjugated goat anti-rabbit IgG (HRP; catalog no. sc-2004; dilution, 1:2,000) and HRP-conjugated goat anti-mouse IgG (catalog no. sc-2005; dilution, 1:2,000) secondary antibodies were purchased from Santa Cruz Biotechnology, Inc. Primary antibodies against caspase-9 (catalog no. 9501; dilution, 1:1,000), caspase-3 (catalog no. 9664; dilution, 1:1,000), JNK (catalog no. 9258; dilution, 1:1,000), phosphorylated (p)-JNK (catalog no. 4668; dilution, 1:1,000), ERK (catalog no. 4695; dilution, 1:1,000), p-ERK (catalog no. 4370; dilution, 1:1,000), p38 (catalog no. 9212; dilution, 1:1,000) and p-p38 (catalog no. 4511; dilution, 1:1,000) antibodies were purchased from Cell Signaling Technology, Inc. All other chemicals and reagents were of the highest analytical grade.

Cell culture. The human melanoma A2058 and human keratinocyte $\mathrm{HaCaT}$ cell lines were purchased from the Korean Cell Line Bank (Seoul, Korea) and Amore Pacific (Yongin, Gyeonggi-do, Republic of Korea). respectively. Cells were maintained at $37^{\circ} \mathrm{C}$ in Dulbecco's modified Eagle's medium (DMEM; Gibco, Thermo Fisher Scientific, Inc., Waltham, MA, USA), supplemented with $10 \%$ fetal bovine serum (Invitrogen; Thermo Fisher Scientific, Inc.), $100 \mathrm{U} / \mathrm{ml}$ penicillin and $100 \mu \mathrm{g} / \mathrm{ml}$ streptomycin (Gibco; Thermo Fisher Scientific, Inc.). Cells were incubated at $37^{\circ} \mathrm{C}$ in an incubator with a humidified atmosphere containing $5 \% \mathrm{CO}_{2}$ and were subcultured every 2 to 3 days. Cell counts were performed using a hemocytometer from Hausser Scientific (Horsham, PA, USA).

Cell viability assay. The cytotoxic effects of MOF extract on the A2058 and HaCaT cell lines were estimated colorimetrically using the MTT method, which is based on the reduction of tetrazolium salt by mitochondrial dehydrogenase in viable cells (18). The cells were seeded on a 96-well plate (density,
$2 \times 10^{6}$ cells $/ \mathrm{ml}$ ) and were then treated with MOF extract at final concentrations of $0,50,75$ and $100 \mu \mathrm{g} / \mathrm{ml}$. After $72 \mathrm{~h}$ of incubation at $37^{\circ} \mathrm{C}, 50 \mu \mathrm{l}$ MTT solution $(2 \mathrm{mg} / \mathrm{ml})$ was added to each well at a final concentration of $0.4 \mathrm{mg} / \mathrm{ml}$. After $2 \mathrm{~h}$ of incubation at $37^{\circ} \mathrm{C}$, the supernatants were aspirated and replaced with $150 \mu 1$ dimethyl sulfoxide to dissolve the formazan product. The absorbance at $540 \mathrm{~nm}$ was then read using a spectrophotometric plate reader (model 550; Bio-Rad Laboratories, Inc., Hercules, CA, USA). The results were calculated as percentages relative to the unexposed control.

Nuclear staining with Hoechst 33258. The nuclear morphology of the cells was observed using the DNA-specific blue fluorescent dye Hoechst 33258. The viable cells were stained homogeneously, whereas the apoptotic cells that exhibited chromatin condensation or nuclear fragmentation were not stained (19). The A2058 cells were treated with MOF extract at the various concentrations $(0,50,75,100 \mu \mathrm{g} / \mathrm{ml})$. Cells were then fixed for $30 \mathrm{~min}$ at $37^{\circ} \mathrm{C}$ in $100 \%$ methanol, washed with PBS and stained with $2 \mu \mathrm{g} / \mathrm{ml}$ Hoechst 33258 (Sigma-Aldrich; Merck KGaA). The cells were observed under a BX51 fluorescence microscope (magnification, x200) and images were captured with a DP70 camera (Olympus Corporation, Tokyo, Japan).

Determination of ROS levels. Intracellular ROS generation was assessed using the stable nonpolar dye 2',7'-dichlorodihydrofluorescein diacetate $\left(\mathrm{H}_{2} \mathrm{DCF}-\mathrm{DA}\right.$; Sigma-Aldrich; Merck $\mathrm{KGaA}$ ), which readily diffuses into the cells (20). Following treatment with MOF extract $(100 \mu \mathrm{g} / \mathrm{ml})$ for $24 \mathrm{~h}$ at $37^{\circ} \mathrm{C}$, the A2058 cells were incubated at $37^{\circ} \mathrm{C}$ with $25 \mu \mathrm{M} \mathrm{H}_{2}$ DCF-DA for $30 \mathrm{~min}$, and then washed twice with ice-cold PBS. The ROS production was measured using a FACSCalibur flow cytometer (BD Biosciences, San Jose, CA, USA). To cells grown in 6-well plates $\left(1 \times 10^{6}\right.$ cells $\left./ \mathrm{ml}\right)$ for $24 \mathrm{~h}$, an antioxidant $\mathrm{N}$-acetyl-L-cystein (NAC; $2 \mathrm{mM}$ ) was added for $1 \mathrm{~h}$ prior to exposing them to $100 \mu \mathrm{g} / \mathrm{ml} \mathrm{MOF}$ extract for $72 \mathrm{~h}$ at $37^{\circ} \mathrm{C}$. A total of $25 \mu \mathrm{M}$ of $\mathrm{H}_{2}$ DCF-DA was then added and the cells incubated for $30 \mathrm{~min}$ at $37^{\circ} \mathrm{C}$, and then washed twice with ice-cold PBS. The ROS production was evaluated using a FACSCalibur flow cytometer (BD Biosciences).

Cell cycle analysis. Cell cycle analysis was performed to determine the proportion of apoptotic sub-G1 hypodiploid cells (21). The A2058 cells were plated on 6-well plates $\left(1 \times 10^{6}\right.$ cells $\left./ \mathrm{ml}\right)$ and incubated for $24 \mathrm{~h}$ at $37^{\circ} \mathrm{C}$. The cells were treated with MOF extract $(0,50,75,100 \mu \mathrm{g} / \mathrm{ml})$ and incubated for $72 \mathrm{~h}$ at $37^{\circ} \mathrm{C}$, following which they were trypsinized, harvested and washed with PBS. The pellet was fixed using ice-cold $70 \%$ ethanol at $4^{\circ} \mathrm{C}$ for $30 \mathrm{~min}$. The cells were then washed once with PBS and resuspended in $50 \mu \mathrm{g} / \mathrm{ml}$ ice-cold propidium iodide (PI) containing $50 \mu \mathrm{g} / \mathrm{ml}$ RNase A in PBS (pH 7.4) for $30 \mathrm{~min}$ in the dark. Fluorescence emitted from the PI-DNA complex was quantified using a FACSCalibur flow cytometer.

Apoptosis analysis. An Annexin V-PI double staining assay was performed to differentiate early and late apoptosis stages. The assay was determined using an ApoScan ${ }^{\mathrm{TM}}$ Annexin V-fluorescein isothiocyanate (FITC) apoptosis detection kit (BioBud Co. Ltd., Seoul, Korea) in the MOF 
extract-treated A2058 cells. Cells were trypsinized, harvested and washed with PBS, and were subsequently were resuspended in $500 \mu \mathrm{l} 1 \mathrm{X}$ binding buffer (50 mM HEPES, $700 \mathrm{mM}$ $\mathrm{NaCl}, 12.5 \mathrm{mM} \mathrm{CaCl}_{2}, \mathrm{PH}$ 7.4) and incubated with $1.25 \mu \mathrm{l}$ Annexin V-FITC $(200 \mu \mathrm{g} / \mathrm{ml})$ at room temperature for $15 \mathrm{~min}$. The supernatant was then removed following centrifugation at $400 \mathrm{x} \mathrm{g}$ for $10 \mathrm{~min}$ at $4^{\circ} \mathrm{C}$. The cells were then resuspended in $500 \mu \mathrm{l} 1 \mathrm{X}$ binding buffer, and cell suspensions were stained with $10 \mu \mathrm{l} \mathrm{PI}(30 \mu \mathrm{g} / \mathrm{ml})$ at $4^{\circ} \mathrm{C}$ in the dark. Fluorescence was quantified using a FACSCalibur flow cytometer. The number of cells in early and late apoptosis was determined as the percentage of Annexin $\mathrm{V}^{+} / \mathrm{PI}^{-}$or Annexin $\mathrm{V}^{+} / \mathrm{PI}^{+}$cells, respectively.

Western blot analysis. Western blot analyses were performed as previously described (22). The cells were cultured, harvested and lysed on ice for $30 \mathrm{~min}$ in lysis buffer $(120 \mathrm{mM}$ $\mathrm{NaCl}, 40 \mathrm{mM}, \mathrm{pH} 8.0$, and $0.1 \%$ nonyl phenoxypolyethoxylethanol) and were then centrifuged at $13,000 \mathrm{x}$ g for $15 \mathrm{~min}$ at $4^{\circ} \mathrm{C}$. Lysates from each sample were mixed with $5 \mathrm{X}$ sample buffer $(0.375 \mathrm{M}$ Tris-HCl, $5 \%$ SDS, 5\% 2-mercaptoethanol, $50 \%$ glycerol and $0.05 \%$ bromophenol blue, $\mathrm{pH}$ 6.8) and were then heated to $95^{\circ} \mathrm{C}$ for $5 \mathrm{~min}$. Equal amounts of protein $(25 \mu \mathrm{g})$ were separated by SDS-PAGE (12\% gel) and were transferred onto nitrocellulose membranes. The membranes were then washed with TBS $(10 \mathrm{mM}$ Tris- $\mathrm{HCl}$ and $150 \mathrm{mM}$ $\mathrm{NaCl}$ ) containing $0.05 \%$ Tween-20 (TBST), and were then blocked in TBST containing 5\% nonfat dried milk. The membranes were then incubated with the aforementioned specific primary antibodies overnight at $4^{\circ} \mathrm{C}$. Subsequent to 3 washes in TBST, the membranes were incubated with the appropriate HRP-conjugated secondary antibodies for $1 \mathrm{~h}$ at room temperature. The membranes were then washed 3 times in TBST with 15 min between each step, and protein detection was performed using an enhanced chemiluminescence western blotting detection ECL kit (Bio-Rad, Hercules, CA, USA). The intensity of each band was analyzed using Image $\mathrm{J}$ software (version k 1.45; National Institute of Health, Bethesda, MD, USA). The expression level of individual proteins in the MOF-treated cells was evaluated and expressed relative to that of the control, of which the expression level was designated as 1.0 .

Statistical analysis. SPSS software (version 22.0; IBM SPSS, Armonk, NY, USA) was used to analyze the data. The results were subjected to analysis of variance, followed by Tukey's range test in order to analyze the differences between conditions. In each case, $\mathrm{P}<0.05$ was considered to indicate a statistically significant difference. All measurements were made in triplicate, and all values are presented as the mean \pm standard deviation.

\section{Results}

Cytotoxic effects of MOF extract in A2058 and HaCaT cell lines. To examine the proliferation inhibitory effects of MOF extract, human melanoma A2058 cells were exposed to MOF extract at concentrations of 50,75 and $100 \mu \mathrm{g} / \mathrm{ml}$ for $72 \mathrm{~h}$, prior to the cell viability being determined using an MTT assay. As presented in Fig. 1A, MOF extract decreased the viability

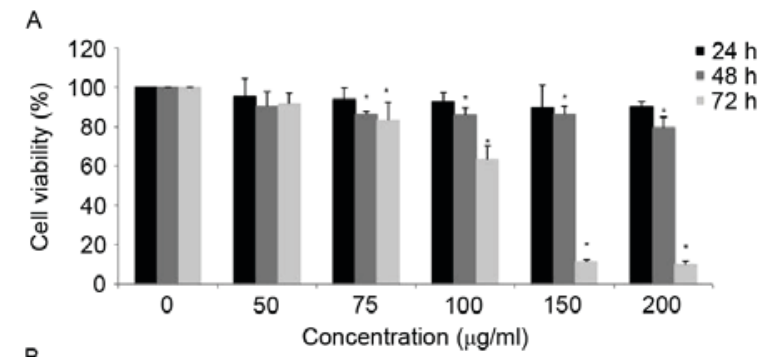

B

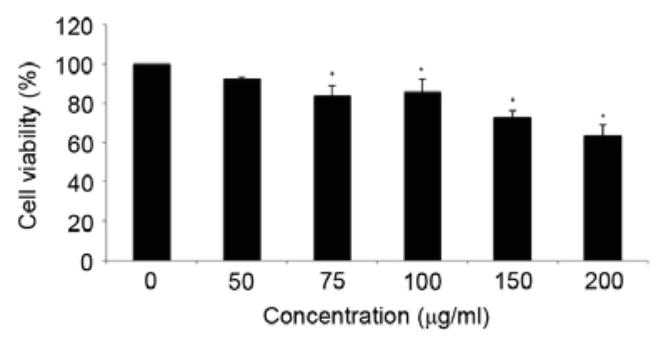

Figure 1. Cytotoxic effects of MOF extract on (A) A2058 and (B) HaCaT cells. Cell viability at the indicated concentrations of MOF extract from the A2058 and HaCaT cell lines was assessed for $72 \mathrm{~h}$, using MTT assays. ${ }^{*} \mathrm{P}<0.05$ vs. control cells. MOF, Moringa oleifera fruit.

of A2058 cells in a dose-dependent manner. The viability of MOF extract-treated A2058 cells was decreased to 91.6, 83.1 and $63.5 \%$ at concentrations of 50,75 and $100 \mu \mathrm{g} / \mathrm{ml}$ for $72 \mathrm{~h}$, respectively. At concentrations of 150 and $200 \mu \mathrm{g} / \mathrm{ml}$, the MOF extract markedly decreased the cell proliferation to 11.3 and $10.1 \%$, respectively. To compare the cytotoxic effects of MOF extract in human keratinocyte $\mathrm{HaCaT}$ cells, the $\mathrm{HaCaT}$ cells were treated with concentrations of MOF extract of 50, $75,100,150$ and $200 \mu \mathrm{g} / \mathrm{ml}$ for $72 \mathrm{~h}$. The results indicated that $\mathrm{HaCaT}$ cells were more resistant to MOF extract-induced cytotoxicity compared with human melanoma A2058 cells (Fig. 1B). Therefore, MOF extract concentrations of 50, 75 and $100 \mu \mathrm{g} / \mathrm{ml}$ were selected for subsequent experiments.

Induction of apoptosis in A2058 cells. The apoptogenic property of MOF extract was investigated through morphological changes in A2058 cells. Nuclear Hoechst 33258 staining was performed in order to determine whether the anti-proliferative effect of MOF extract was due to apoptosis. As presented in Fig. 2, A2058 cells treated with MOF extract exhibited a number of morphological changes, including membrane blebbing, nuclear fragmentation, chromatin condensation and an increased density of apoptotic bodies compared with the untreated control cells. The number of apoptotic cells increased in a dose-dependent manner, which is consistent with the results of the MTT assay.

Effects on generation of ROS. To investigate the possible underlying mechanisms of MOF extract-induced apoptosis, ROS production was examined using the specific fluorescent probe $\mathrm{H}_{2} \mathrm{DCF}-\mathrm{DA}$. Using flow cytometry, MOF extract caused a rightward shift for $\mathrm{H}_{2} \mathrm{DCF}-\mathrm{DA}$, indicating increased production of hydroxyl radicals and hydrogen peroxide, compared with the control, followed by cell death (Fig. 3A). However, co-treatment with MOF extract and NAC slightly attenuated ROS production, compared with MOF extract alone, indicating that NAC may act as a scavenger of ROS (Fig. 3B). The results 

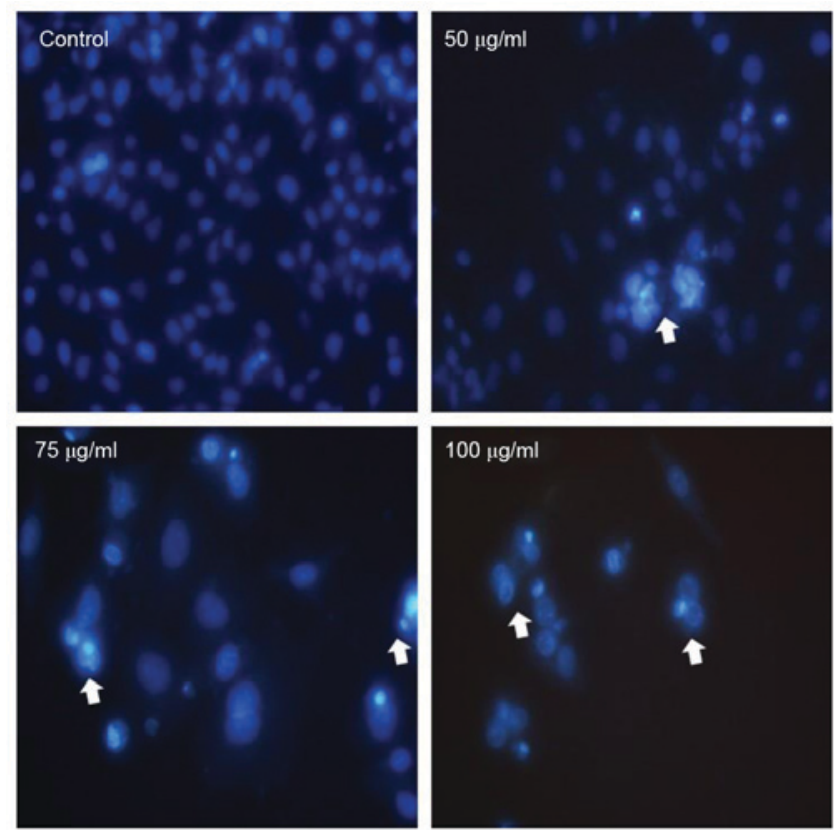

Figure 2. Induction of apoptosis by Moringa oleifera fruit on A2058 cells at the concentrations indicated. The formation of apoptotic bodies (arrows) in Hoechst 33258-stained cells was observed using fluorescence microscopy (magnification, $\mathrm{x} 400$ ).

demonstrated that ROS is involved in MOF extract-mediated apoptotic processes.

Effects on cell cycle progression in A2058 cells. To investigate the effect of MOF extract on cell cycle progression, flow cytometry was performed with 50,75 and $100 \mu \mathrm{g} / \mathrm{ml}$ MOF extract. As presented in Fig. 4, 13.9\% of control cells were in sub- $\mathrm{G}_{1}$ phase, whereas $29.9,31.1$ and $57.5 \%$ of MOF extract-treated cells were in sub- $\mathrm{G}_{1}$ phase, at concentrations of 50,75 and $100 \mu \mathrm{g} / \mathrm{ml}$, respectively. This was accompanied by a significant decrease in the numbers of A2058 cells in S phase of $28.5,20.5$ and $16.3 \%$, and $\mathrm{G} 2 / \mathrm{M}$ phase of $23.1,18.7$ and 6.9 at 50,75 and $100 \mu \mathrm{g} / \mathrm{ml}$, respectively.

Effects on apoptosis in A2058 cells. In order to quantify the percentage of apoptotic cells, flow cytometry analysis was performed using double staining with Annexin V and PI. The Annexin $\mathrm{V}^{-} / \mathrm{PI}^{-}$population was considered to account for unaffected cells, the Annexin $\mathrm{V}^{+} / \mathrm{PI}^{-}$population represented early apoptosis, the Annexin $\mathrm{V}^{+} / \mathrm{PI}^{+}$population represented late apoptosis and the Annexin $\mathrm{V}^{-} / \mathrm{PI}^{+}$population represented necrosis. The results demonstrated that the treatment of the cells with MOF extract significantly increased the percentage of apoptotic cells compared with untreated control cells (Fig. 5). MOF extract-treated A2058 cells exhibited increased proportions of early apoptotic cells to $6.5,27.3$ and $31.9 \%$ at 50,75 and $100 \mu \mathrm{g} / \mathrm{ml}$, respectively, compared with $3.2 \%$ for the control. The proportions of late apoptotic cells also increased to $11.2,21.6$ and $26.6 \%$ at 50, 75 and $100 \mu \mathrm{g} / \mathrm{ml}$, respectively, compared with $9.0 \%$ for the control. The total number of apoptotic cells increased from $12.2 \%$ in control cells to $17.7,48.9$ and $58.5 \%$ at 50,75 and $100 \mu \mathrm{g} / \mathrm{ml}$, respectively. The proportion of early apoptotic cells was increased at $50 \mu \mathrm{g} / \mathrm{ml}$ compared with that of late
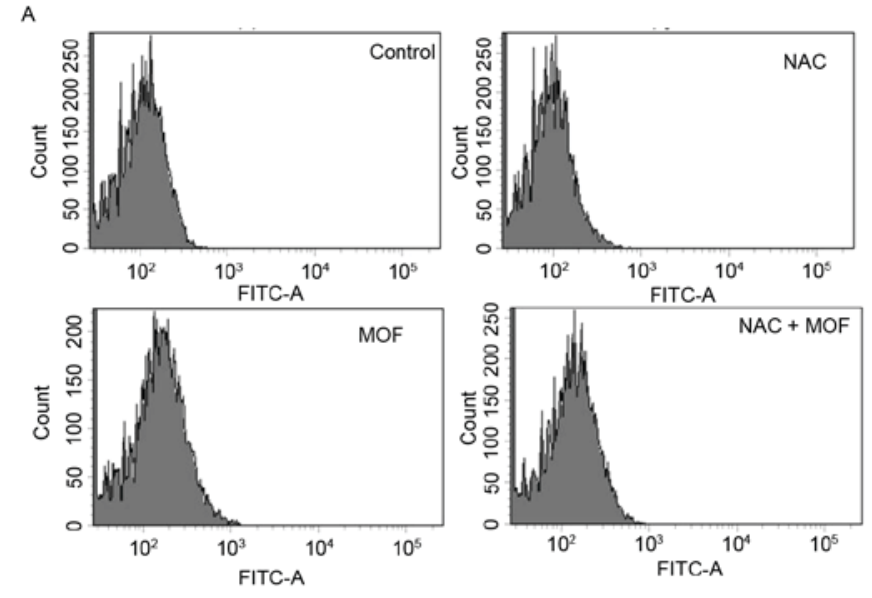

B

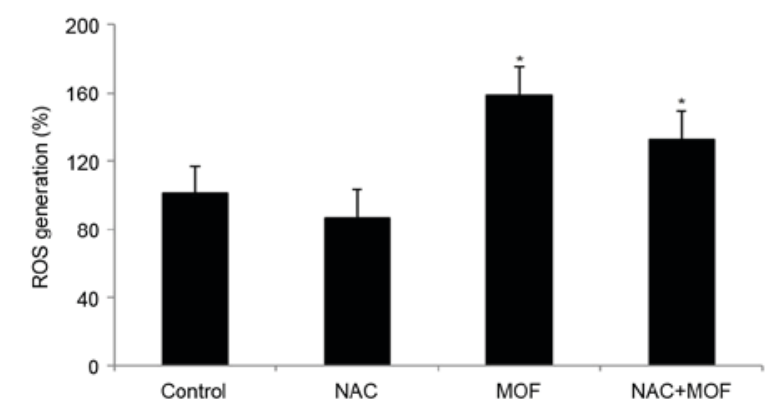

Figure 3. Alterations in ROS levels on MOF extract-treated A2058 cells. (A) 2',7'-dichlorodihydrofluorescein diacetate staining was conducted to measure alterations in the ROS level. Following incubation with NAC and MOF extract for $72 \mathrm{~h}$, ROS levels were measured by flow cytometry. (B) Statistical analysis of apoptosis. ${ }^{*} \mathrm{P}<0.05$ vs. control cells. FITC, fluorescein isothiocyanate; ROS, reactive oxygen species; MOF, Moringa oleifera fruit; NAC, N-acetyl-L-cysteine.

apoptotic cells. However, the population of late apoptotic cells was increased compared with that of early apoptotic cells. From these results, it is hypothesized that anti-proliferative effects of MOF extract in A2058 melanoma cells may be mediated by the induction of cell apoptosis in a dose-dependent manner.

Effects on Bcl-2, Bax and caspase expression in A2058 cells. In order to investigate the effects of MOF extract on apoptosis in A2058 cells, the expression levels of apoptotic regulatory proteins, including $\mathrm{Bcl}-2$, Bax and caspases, were examined. As presented in Fig. 6, MOF extract increased Bax protein expression, but decreased the expression of $\mathrm{Bcl}-2$, in a dose-dependent manner. The disruption of the mitochondrial plasma membrane by MOF extract was followed by the activation of the cleaved caspase-3 and 9 and target protein, PARP, respectively. These results, together with the $\mathrm{Bax} / \mathrm{Bcl}-2$ ratio, indicated that the MOF extract may induce apoptosis through the regulation of apoptosis-associated protein expression in human melanoma A2058 cells.

Effects on mitogen-activated protein kinase (MAPK) expression in A2058 cells. The MAPKs, including JNK, ERK and p38 kinase, are present in all eukaryotes and have been demonstrated to perform central roles in regulating cell proliferation, differentiation and apoptosis (23). In order to investigate the effects of MOF extract in A2058 cells, the 

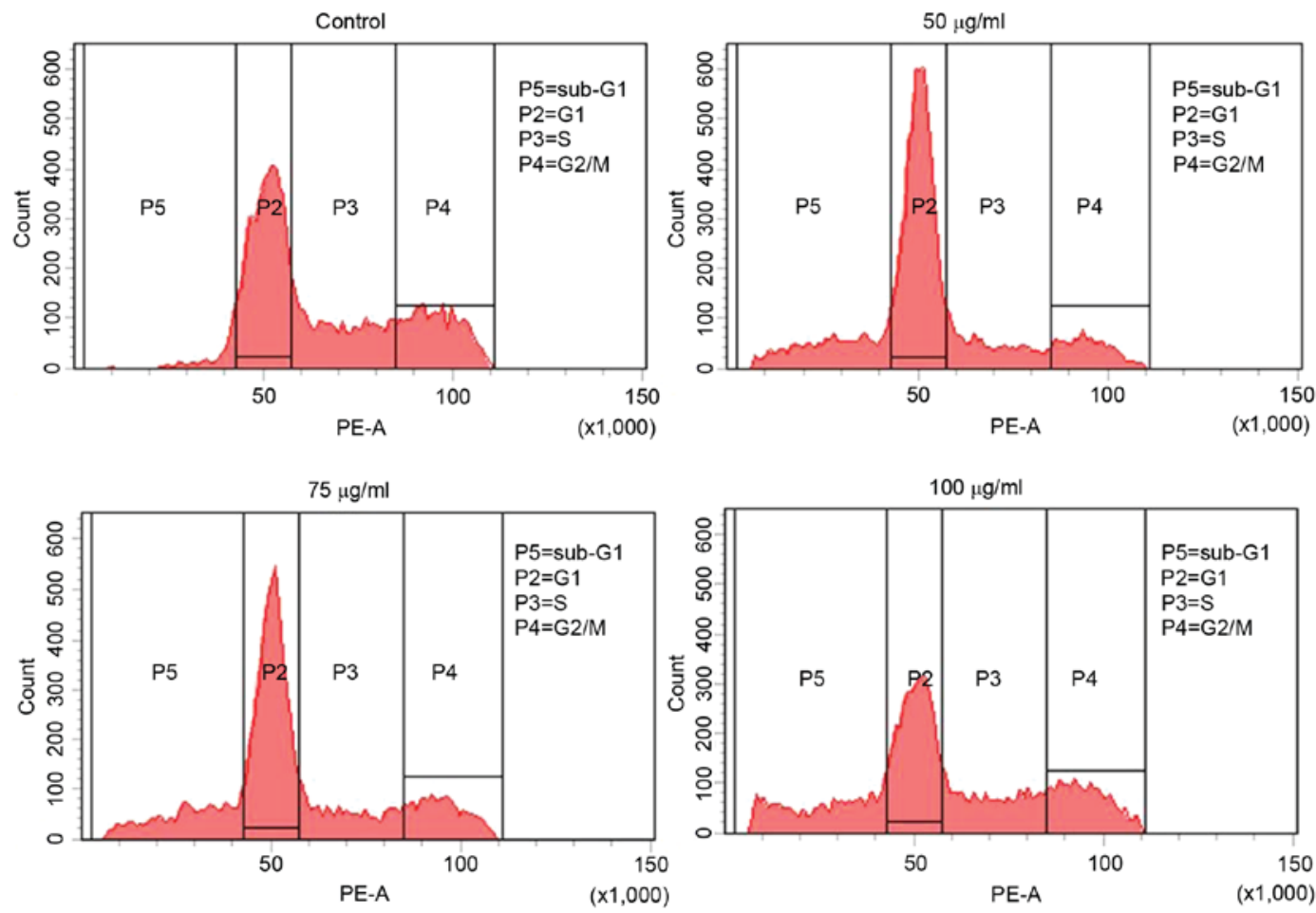

Figure 4. Effects of various concentrations of Moringa oleifera fruit on the cell cycle distribution in A2058 cells. The sub-G1 cells were detected by flow cytometry following propidium iodide staining.

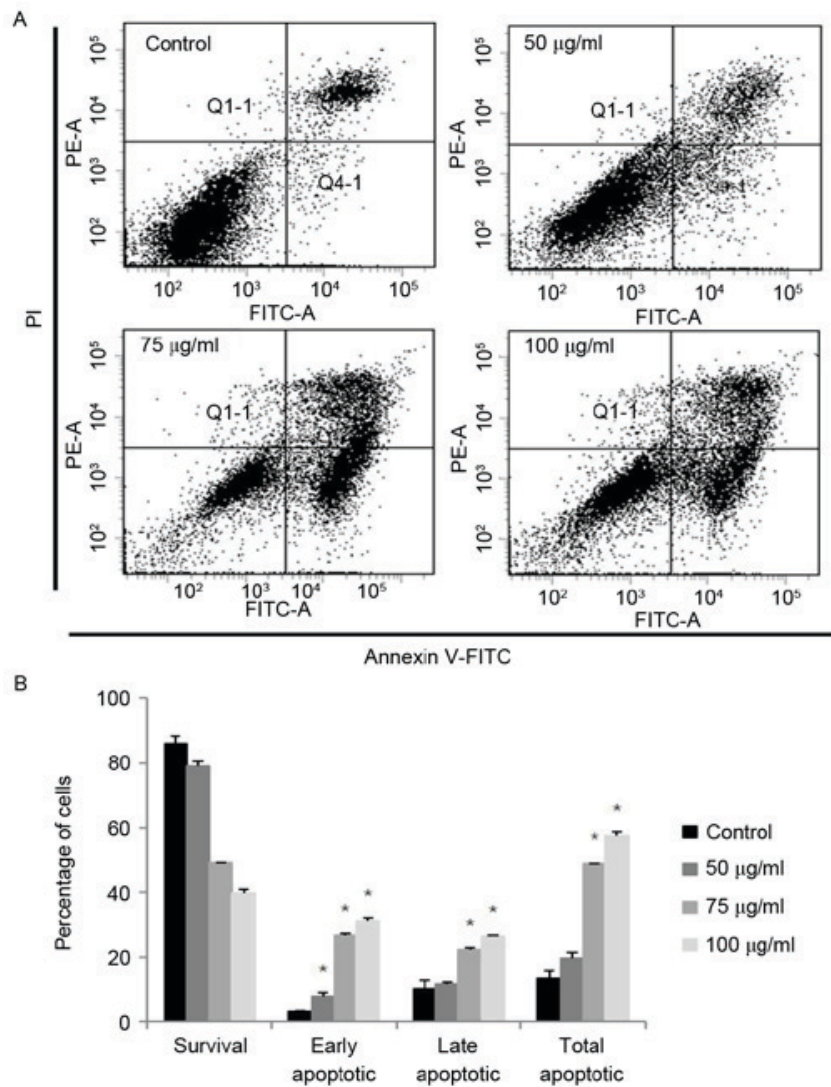

Figure 5. Induction of apoptosis by MOF extract in A2058 cells. (A) Flow cytometric analysis of A2058 cells incubated with MOF extract for $72 \mathrm{~h}$. The lower-right quadrant represents Annexin V-stained cells (early-phase apoptotic cells). The upper-right quadrant represents PI- and annexin V-stained cells (late-phase apoptotic cells). (B) Quantification of apoptosis. "P<0.05 vs. control cells. MOF, Moringa oleifera fruit; PI, propidium iodide; FITC, fluorescein isothiocyanate.

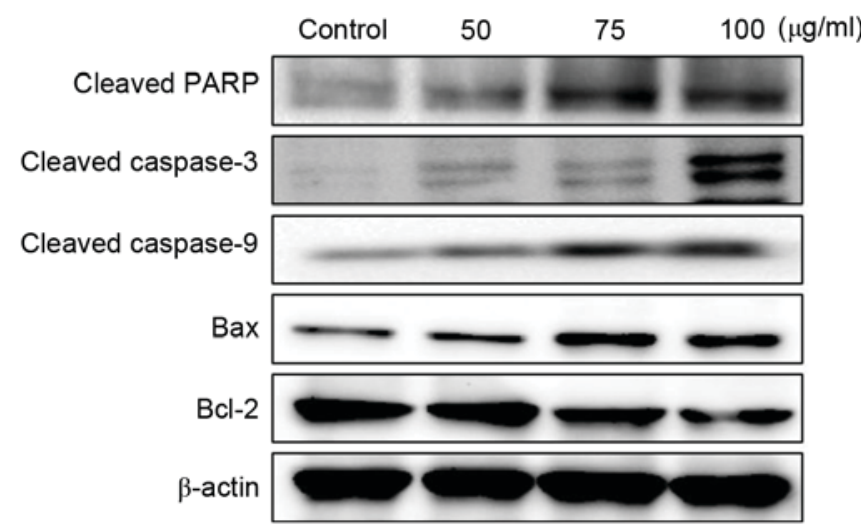

Figure 6. Expression of caspase-associated proteins by Moringa oleifera fruit by A2058 cells. Cell lysates were electrophoresed, and cleaved caspase-3, caspase-9 and PARP were detected using western blot analysis. PARP, poly (ADP-ribose) polymerase; Bcl-2, B-cell lymphoma-2; Bax, Bcl-2-associated X protein.

phosphorylation of MAPKs was determined. As presented in Fig. 7A, expression levels of non-phosphorylated ERK, JNK and p38 were unchanged with MOF extract. By contrast, accumulation of p-ERK and p-JNK markedly increased in a time-dependent manner. These results indicated that MOF extract induces apoptosis through activation of ERK and JNK in A2058 cells. In order to determine the effects of ERK and JNK on MOF extract-induced A2058 cytotoxicity, the kinase-specific inhibitors SP600125 and PD98058 were used. As presented in Fig. 7B, co-treatment with MOF extract and inhibitors blocked MOF extract-mediated p-ERK and p-JNK accumulation. The cumulative results 


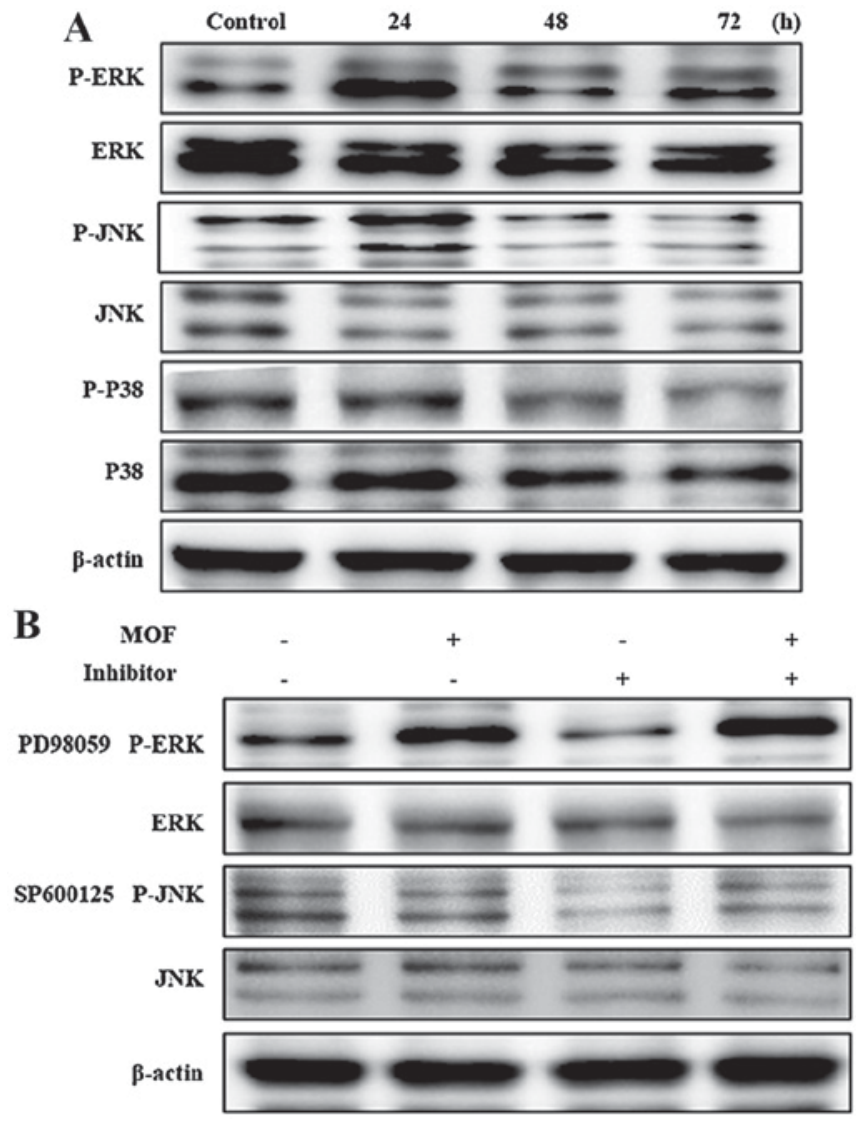

Figure 7. Regulation of mitogen-activated protein kinase signaling by MOF extract-induced A2058 cells. (A) Equal amounts of cell lysates were electrophoresed and apoptosis-associated protein expression was detected using western blot analysis. (B) The cells were stimulated with MOF extract following pretreatment with SP600125 and PD98059, respectively. MOF, Moringa oleifera fruit; P-, phosphorylated; ERK, extracellular-signalregulated kinase; JNK, c-Jun N-terminal kinase.

indicated that ERK and JNK are involved in the regulation of MOF extract-induced mitochondrial apoptosis in A2058 cells.

\section{Discussion}

The incidence rate of malignant melanoma has continued to increase by between 3 and $7 \%$ each year in Western countries (24). In addition, as the climate changes, exposure to harmful ultraviolet (UV) rays has become a concern due to increasing incidence of various types of skin cancer (25). As malignant melanoma exhibits resistance to chemotherapy or immunotherapy, complete treatment has become problematic $(26,27)$.

Seeds, roots, leaves, flowers and bark of Moringa oleifera have been used as materials for cosmetics and medicine (28). As the anti-inflammatory, anticancer and antioxidant effects of MOF extract have been validated $(29,30)$, the present study investigated the effects of MOF extract on apoptosis and ROS accumulation in malignant melanoma cells.

ROS are generated by active processes in normal cells and are associated with various biological processes, including cell differentiation and gene expression (31). Therefore, ROS homeostasis is important for cell viability and survival. Although the association between ROS and apoptosis has been reported to be contradictory, ROS perform a role as an intermediate mediator that delivers signals for apoptosis (32).

MAPKs are protein kinases activated by a variety of stimuli, and regulate cell proliferation, differentiation, proliferation and death $(33,34)$. MAPKs consist of JNK, p38 and ERK proteins (35). In general, ERK is activated by growth factors, cytokines and phorbol ester and is involved in cell proliferation or differentiation (36). By contrast, JNK and p38 are activated by proinflammatory cytokines, UV irradiation, heat, osmotic shock, hydrogen peroxide and DNA damage induced by stress and is involved in proliferation inhibition and apoptosis (37-40). However, previous studies have reported that ERK, JNK and p38 are involved in cell survival and death $(41,42)$. The present study revealed that JNK and ERK are involved in the apoptotic effects of MOF extract.

Apoptosis, also termed programmed cell death, is required to control the number of normal cells and is induced by various types of damage (43). In addition, apoptosis serves as an important control mechanism of homeostasis, as it is involved in the removal of harmful cells, and is induced by internal and external signaling (44). Upon apoptosis, cells are morphologically characterized by membrane detachment, membrane blebbing, nuclear condensation, exposure of phosphatidylserine to the extracellular space and DNA fragmentation (45). Apoptosis may be initiated by one of two pathways: The intrinsic or the extrinsic pathway (46). In the intrinsic pathway, loss of mitochondrial transmembrane potential results in the release of cytochrome $c$ into the cytosol, formation of apoptotic protease-activating factor 1 (Apaf-1) and activation of caspase-9. Caspase-9 then activates downstream caspases-3, -6 and $-7(47,48)$. In the extrinsic pathway, Fas-associated death domain protein and caspase- 8 are activated through Fas and tumor necrosis factor receptors, which are death receptors (49). Bax and Bak proteins are widely known for their cell killing activity (50). Alterations in the expression of Bcl-2 family proteins inhibit dimerization of Bcl-2 family members on the outer mitochondrial membrane, which induces release of mitochondrial proteins, including cytochrome $c$, Apaf-1, second mitochondria-derived activator of caspase/direct inhibitor of apoptosis-binding protein with low $\mathrm{pI}$ and apoptosis-inducing factor, and promotes apoptosis $(51,52)$. Caspase-3 is generally inactive (pro-caspase-3) in cells and activated by death signaling, which catalyzes proteolytic cleavage of PARP as an apoptosis-specific marker $(53,54)$. In the present study, the $\mathrm{Bax} / \mathrm{Bcl}-2$ ratio was identified to have increased and PARP was cleaved by caspase- 3 via the caspase- 9 signaling pathway.

The results of the present study revealed the apoptotic effects of MOF extract via ROS production in melanoma cells. Therefore, MOF extract inhibits the proliferation of human melanoma A2058 cells by generating ROS, which regulate expression of proteins involved in survival and apoptosis of cancer cells.

\section{Acknowledgements}

The present study was supported by the International Research and Development Program of the NationalResearch Foundation, by the Ministry of Education, Science and Technology, Republic of Korea (grant no. NRF-2014K1A3A1A09063352). 


\section{References}

1. Singh S, Zafar A, Khan S and Naseem I: Towards therapeutic advances in melanoma management: An overview. Life Sci Feb 23, 2017 (Epub ahead of print).

2. Shayanfar N, Bahari L, Safaie-Naraghi Z, Kamyab K, Gheytanchi E and Rezaei N: Negative HER2/neu amplification using immunohistochemistry and chromogenic in situ hybridization techniques in skin melanoma cases. Asian Pac J Cancer Prev 16: 421-425, 2015.

3. Read RL, Pasquali S, Haydu L, Thompson JF, Stretch JR, Saw RP, Quinn MJ, Shannon K and Spillane AJ: Quality assurance in melanoma surgery: The evolving experience at a large tertiary referral centre. Eur J Surg Oncol 41: 830-836, 2015.

4. Markovic SN, Erickson LA, Rao RD, Weenig RH, Pockaj BA Bardia A, Vachon CM, Schild SE, McWilliams RR, Hand JL, et al: Melanoma melanoma in the 21st century, part 2: Staging, prognosis, and treatment. Mayo Clin Proc 82: 490-513, 2007.

5. Siegel R, Naishadham D and Jemal A: Cancer statistics for Hispanics/Latinos. CA Cancer J Clin 62: 283-298, 2012.

6. Anwar F, Latif S, Ashraf M and Gilani AH: Moringa oleifera: A food plant with multiple medicinal uses. Phytother Res 21: 17-25, 2007.

7. Leone A, Fiorillo G, Criscuoli F, Ravasenghi S, Santagostini L, Fico G, Spadafranca A, Battezzati A, Schiraldi A, Pozzi F, et al: Nutritional characterization and phenolic profiling of Moringa oleifera leaves grown in chad, sahrawi refugee camps, and haiti. Int J Mol Sci 16: 18923-18937, 2015.

8. Bharali R, Tabassum J and Azad MR: Chemomodulatory effect of Moringa oleifera, Lam, on hepatic carcinogen metabolising enzymes, antioxidant parameters and skin papillomagenesis in mice. Asian Pac J Cancer Prev 4: 131-139, 2003.

9. Siddhuraju P and Becker K: Antioxidant properties of various solvent extracts of total phenolic constituents from three different agroclimatic origins of drumstick tree (Moringa oleifera Lam.) leaves. J Agric Food Chem 51: 2144-2155, 2003.

10. Kim DH, Park KW, Chae IG, Kundu J, Kim EH, Kundu JK and Chun KS: Carnosic acid inhibits STAT3 signaling and induces apoptosis through generation of ROS in human colon cancer HCT116 cells. Mol Carcinog 55: 1096-1110, 2016.

11. Clarke PG and Clarke S: Historic apoptosis. Nature 378: 230 , 1995.

12. Stadtman ER: Protein oxidation in aging and age-related diseases. Ann N Y Acad Sci 928: 22-38, 2001.

13. Sauer H, Wartenberg M and Hescheler J: Reactive oxygen species as intracellular messengers during cell growth and differentiation. Cell Physiol Biochem 11: 173-186, 2001.

14. Kuo PL, Chen CY and Hsu YL: Isoobtusilactone A induces cell cycle arrest and apoptosis through reactive oxygen species/apoptosis signal-regulating kinase 1 signaling pathway in human breast cancer cells. Cancer Res 67: 7406-7420, 2007.

15. Burris HA III: Overcoming acquired resistance to anticancer therapy: Focus on the PI3K/AKT/mTOR pathway. Cancer Chemother Pharmacol 71: 829-842, 2013.

16. Alcazar O, Achberger S, Aldrich W, Hu Z, Negrotto S, Saunthararajah Y and Triozzi P: Epigenetic regulation by decitabine of melanoma differentiation in vitro and in vivo. Int $J$ Cancer 131: 18-29, 2012.

17. Triozzi PL, Aldrich W, Achberger S, Ponnazhagan S, Alcazar O and Saunthararajah Y: Differential effects of low-dose decitabine on immune effector and suppressor responses in melanoma-bearing mice. Cancer Immunol Immunother 61: $1441-1450,2012$

18. Carmichael J, DeGraff WG, Gazder AF, Minnan JD and Mitchell JB: Evaluation of a tetrazolium-based semiautomated colorimetric assay: Assessment of chemosensitivity testing. Cancer Res 47: 936-942, 1987.

19. Lizard G, Fournel S, Genestier L, Dgedin N, Chaput C, Flacher M, Mutin M, Panaye G and Revillard JP: Kinetics of plasma membrane and mitochondrial alterations in cells undergoing apoptosis. Cytometry 21: 275-283, 1995.

20. Cathcart R, Schwiers E and Ames BN: Detection of picomole levels of hydroperoxides using a fluorescent dichlorofluorescein assay. Anal Biochem 134: 111-116, 1983.

21. Nicoletti I, Migliorati G, Pagliacci MC, Grignani F and Riccardi C: A rapid and simple method for measuring thymocyte apoptosis by propidium iodide staining and flow cytometry. J Immunol Methods 139: 271-279, 1991 .
22. Ryu MJ and Chung HS: [10]-Gingerol induces mitochondrial apoptosis through activation of MAPK pathway in HCT116 human colon cancer cells. In Vitro Cell Dev Biol Anim 51: 92-101, 2015

23. Stadheim TA and Kucera GI: c-Jun N-terminal kinase/stress-activated protein kinase (JNK/SAPK) is required for mitoxantrone- and anisomycin-induced apoptosis in HL-60 cells. Leuk Res 26: 55-65, 2002.

24. Erdei E and Torres SM: A new understanding in the epidemiology of melanoma. Expert Rev Anticancer Ther 10: 1811-1823, 2010.

25. Diffey B: Climate change, ozone depletion and the impact on ultraviolet exposure of human skin. Phys Med Biol 49: R1-R11, 2004.

26. Jerant AF, Johnson JT, Sheridan CD and Caffrey TJ: Early detection and treatment of skin cancer. Am Fam Physician 62: $357-368,2000$

27. Lopez RF, Lange N, Guy R and Bentley MV: Photodynamic therapy of skin cancer: Controlled drug delivery of 5-ALA and its esters. Adv Drug Deliv Rev 56: 77-94, 2004

28. Rebecca HSU, Sharon M, Arbainsyah A and de Witte L: Moringa oleifera: Medicinal and Socio-Economic Uses. In: International Course on Economic Botany. National Herbarium Leiden, The Netherlands, pp2-6, 2006

29. Guevara AP, Vargas C, Sakurai H, Fujiwara Y, Hashimoto K Maoka T, Kozuka M, Ito Y, Tokuda $\mathrm{H}$ and Nishino H: An antitumor promoter from Moringa oleifera Lam. Mutat Res 440: 181-188, 1999.

30. Mahajan SG and Mehta AA: Effect of Moringa oleifera Lam. seed extract on ovalbumin-induced airway inflammation in guinea pigs. Inhal Toxicol 20: 897-909, 2008.

31. Rhee SG: Cell signaling. $\mathrm{H} 2 \mathrm{O} 2$, a necessary evil for cell signaling. Science 312: 1882-1883, 2006.

32. Ozben T: Oxidative stress and apoptosis: Impact on cancer therapy. J Pharm Sci 96: 2181-2196, 2007.

33. McCubrey JA, Lahair MM and Franklin RA: Reactive oxygen species-induced activation of the MAP kinase signaling pathways. Antioxid. Redox Signal 8: 1775-1789, 2006.

34. Dhillon AS, Hagan S, Rath O and Kolch W: MAP kinase signalling pathways in cancer. Oncogene 26: 3279-3290, 2007

35. Hanawa N, Shinohara M, Saberi B, Gaarde WA, Han D and Kaplowitz N: Role of JNK translocation to mitochondria leading to inhibition of mitochondria bioenergetics in acetaminophen-induced liver injury. J Biol Chem 283: 13565-13577, 2008.

36. Roberts PJ and Der CJ: Targeting the Raf-MEK-ERK mitogen-activated protein kinase cascade for the treatment of cancer. Oncogene 26: 3291-3310, 2007.

37. Dérijard B, Hibi M, Wu IH, Barrett T, Su B, Deng T, Karin M and Davis RJ: JNK1: A protein kinase stimulated by UV light and $\mathrm{Ha}-\mathrm{Ras}$ that binds and phosphorylates the c-Jun activation domain. Cell 76: 1025, 1994.

38. Kyriakis JM, Banerjee P, Nikolakaki E, Dai T, Rubie EA, Ahmad MF, Avruch J and Woodgett JR: The stress-activated protein kinase subfamily of c-Jun kinases. Nature 369: 156-160, 1994.

39. Raingeaud J, Gupta S, Rogers J, Dickens M, Han J, Ulevitch R and Davis RJ: Pro-inflammatory cytokines and environmental stress cause p38 mitogen-activated protein kinase activation by dual phosphorylation on tyrosine and threonine. J Biol Chem 270: 7420-7426, 1995.

40. Davis RJ: Signal transduction by the JNK group of MAP kinases Cell 103: 239-252, 2000.

41. Ichijo H: From receptors to stress-activated MAP kinases. Oncogene 18: 6087-6093, 1999.

42. Xia Z, Dickens M, Raingeaud J, Davis RJ and Greenberg ME: Opposing effects of ERK and JNK-p38 MAP kinases on apoptosis. Science 270: 1326-1331, 1995.

43. Strasser A, O'Connor L and Dixit VM: Apoptosis signaling. Ann Rev Biochem 69: 217-245, 2000.

44. Pathak S, Sharma CH, Jayaram HN and Singh N: Apoptotic signaling induced by benzamideriboside: An in vitro study. Mol Cell Biochem 328: 67-73, 2009.

45. Gschwind M and Huber G: Apoptotic cell death induced by beta-amyloid 1-42 peptide is cell type dependent. J Neurochem 65: 292-300, 1995

46. Kiechle FL and Zhang X: Apoptosis: Biochemical aspects and clinical implications. Clin Chim Acta 326: 27-45, 2002.

47. Brenner D and Mak TW: Mitochondrial cell death effectors. Curr Opin Cell Biol 21: 871-877, 2009. 
48. Cain K, Bratton SB and Cohen GM: The Apaf-1 apoptosome: A large caspase-activating complex. Biochimie 84: 203-214, 2002.

49. Bold RJ, Termuhlen PM and McConkey DJ: Apoptosis, cancer and cancer therapy. Surg Oncol 6: 133-142, 1997.

50. Shamas-Din A, Bindner S, Zhu W, Zaltsman Y, Campbell C, Gross A, Leber B, Andrews DW and Fradin C: tBid undergoes multiple conformational changes at the membrane required for Bax activation. J Biol Chem 288: 22111-22127, 2013.

51. Alves NL, van Lier RA and Eldering E: Withdrawal symptoms on display: Bcl-2 members under investigation. Trends Immunol 28 : 26-32, 2007

52. Nagappan A, Park KI, Park HS, Kim JA, Hong GE, Kang SR, Lee H, Kim EH, Lee WS, Won CK and Kim GS: Vitamin C induces apoptosis in AGS cells by down-regulation of 14-3-3 $\sigma$ via a mitochondrial dependent pathway. Food Chem 135: 1920-1928, 2012.
53. Guon TE and Chug HS: Hyperoside and rutin of nelumbo nucifera induce mitochondrial apoptosis through a caspase-dependent mechanism in HT-29 human colon cancer cells. Oncol Lett 11: 2463-2470, 2016

54. Kim KN, Ham YM, Moon JY, Kim MJ, Jung YH, Jeon YJ, Lee NH, Kang N, Yang HM, Kim D and Hyun CG: Acanthoic acid induces cell apoptosis through activation of the p38 MAPK pathway in HL-60 human promyelocytic leukaemia. Food Chem 135: 2112-2117, 2012. 